\title{
Nutritive Value of Desmanthus Associated With Kleingrass During the Establishment Year
}

\author{
E. A. Gonzalez-V., ${ }^{1}$ M. A. Hussey, ${ }^{2}$ and J. A. Ortega-S. ${ }^{3}$ \\ Authors are ${ }^{1}$ Research Scientist, Instituto Nacional de Investigaciones Forestales y Agropecuarias, Campo Experimental de \\ Aldama, Apartado Postal 14, Aldama, Tamaulipas, México 89670; ${ }^{2}$ Associate Director, Texas Agricultural Experiment Station, \\ Professor and Department Head, Soil and Crops Sciences, Texas AઐM University System, College Station, TX 77843; and \\ ${ }^{3}$ Assistant Professor, Animal and Wildlife Sciences Department and Caesar Kleberg Wildlife Research Institute, MSC 228, Texas \\ AઐM University-Kingsville, Kingsville, TX 78363.
}

\begin{abstract}
Seasonal variation in production and quality of warm-season grasses is a limitation for livestock productivity. The use of high quality forage legumes to aid in overcoming this problem can be a management alternative. The objective of this study was to evaluate the nutrient content of kleingrass (Panicum coloratum L.)-bundleflower (Desmanthus sp.) mixtures during the establishment year. Plots were drilled at a $0.15 \mathrm{~m}$ row-spacing with kleingrass sown either alone or in association with Illinois bundleflower (Desmanthus illinoensis [Michx.] MacM.) or desmanthus (Desmanthus pubescens [L.] Willd), which was previously identified as Desmanthus virgatus. Spacings of 0.30, 0.60, and $0.90 \mathrm{~m}$ between rows of bundleflower were used. Plots were planted in April and nutritive value was determined on samples harvested at 60, 90, and 120 days after planting. Age reduced kleingrass crude protein $(\mathrm{CP})$ and increased fiber concentration. The $\mathrm{CP}$ concentration of desmanthus leaves was greater than that of Illinois bundleflower; however, the $\mathrm{CP}$ on a whole-plant basis was greater in Illinois bundleflower. Associations had greater $\mathrm{CP}$ yield than did the kleingrass monoculture. The tannin content was higher in desmanthus than in Illinois bundleflower. In both legumes the leaves had the greatest tannin concentrations, with a mean of $2.1 \%$ and $1.69 \%$ in desmanthus and Illinois bundleflower, respectively. With the exception of calcium (Ca), mineral content declined with increased age in both legumes and the grass. Levels of potassium, sodium, copper, and manganese were greater in kleingrass than in the legumes, while the legumes had greater concentrations of $\mathrm{Ca}$ and magnesium $(\mathrm{Mg})$. Phosphorus and zinc concentrations were similar for kleingrass and legumes. The legumes did not affect the nutrient content of kleingrass when established in association, and the high $\mathrm{CP}$ of both legumes and their high levels of $\mathrm{Ca}$ and $\mathrm{Mg}$ suggest that animals grazing kleingrass-desmanthus associations may benefit nutritionally.
\end{abstract}

\begin{abstract}
Resumen
La variación estacional de la producción y calidad de los forrajes de verano se reconoce como uno de los factores que limitan la productividad de la las explotaciones ganaderas. El uso de leguminosas de alta calidad de forraje puede ser una alternativa de solución a este problema. El objetivo de este estudio fue evaluar el contenido de nutrientes de las asociaciones del zacate klein (Panicum coloratum L.) con dos especies de Desmanthus durante el periodo de establecimiento. El trabajo se realizó cerca de College Station, Texas, por un periodo de dos años. Se prepararon parcelas para sembrar con una distancia entre surcos de $0.15 \mathrm{~m}$, sembrando el pasto klein solo o en asociación con Desmanthus illinoensis (Michx) MacM. ó D. Pubescens (L) Willd, este ultimo previamente identificado como Desmanthus virgatus. La distancia entre surcos establecidos con las leguminosas fue de $0.30,0.60$, y $0.90 \mathrm{~m}$. Las parcelas se sembraron en Abril de cada año, y el contenido de nutrientes se evaluó tomando muestras a los 60, 90, y 120 días después de la siembra. En el zacate klein se redujo el contenido de proteína cruda (PC) e incrementó la fibra al aumentar la edad. En las asociaciones se cosechó mayor cantidad de proteína por unidad de superficie que al sembrar el zacate como monocultivo. La leguminosa $D$. pubescens presentó mayor concentración de taninos. El contenido de taninnos fue superior en las hojas que en tallos de ambas leguminosas, con un promedio de $2.1 \%$ y $1.69 \%$ en D. Pubescens y D. illinoensis respectivamente. Con la excepción del Ca, la concentración de minerales declinó al aumentar la edad tanto en el pasto como en ambas leguminosas. El zacate klein tuvo mayores niveles de $\mathrm{K}, \mathrm{Na}, \mathrm{Cu}, \mathrm{y} \mathrm{Mn}$ que las leguminosas; mientras que las leguminosas mostraron niveles más altos de Ca y Mg. Las concentraciones de $\mathrm{P}$ y $\mathrm{Zn}$ fueron similares en el pasto y ambas especies de Desmanthus. Las leguminosas no afectaron el contenido de nutrientes del zacate klein, ademas de que la alta concentración de PC, Ca, y Mg en ambas leguminosas podrían ayudar a enriquecer la dieta del ganado pastoreando asociaciones del pasto klein y Desmanthus.
\end{abstract}

Key Words: Panicum coloratum, Desmanthus pubescens, Desmanthus illinoensis, bundleflower, grass-legume associations

\section{INTRODUCTION}

At the time of the study, Gonzalez-V. was a PhD student at Texas A\&M University. Correspondence: J. Alfonso Ortega-S., MSC 228, 700 University Blvd, Kingsville, TX 78363-8202. Email: alfonso.ortega@tamuk.edu

Manuscript received 25 August 2003; manuscript accepted 20 January 2005.
Warm-season grasses are generally considered to be of lower quality than temperate grasses or legumes (Skerman and Riveros 1990); because of their higher cell wall content, these warm-season grasses have low digestibility. As forages mature, 


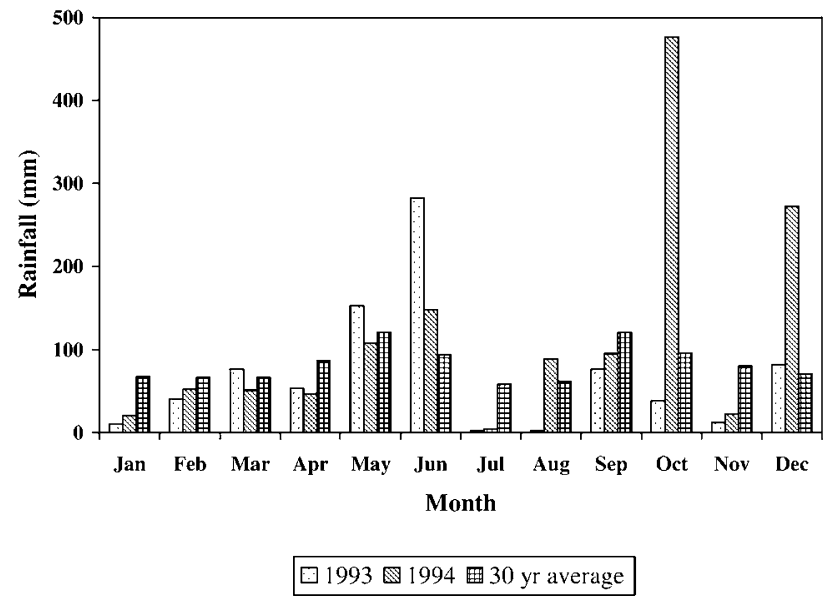

Figure 1. Precipitation at College Station, Texas, during the kleingrass and legumes establishment study.

their crude protein $(\mathrm{CP})$ concentration falls from $12 \%-10 \%$ to $7 \%-4 \%$ or lower (Holechek et al. 2001). Generally, leaves of forbs and shrubs have higher digestibility than grasses. Therefore, grass-legume mixtures could provide a more balanced diet than grasses growing alone (McGinnies and Townsend 1983). Minerals are essential to animal nutrition. Deficiencies or excesses could be responsible for low production and reproductive problems of grazing ruminants (McDowell et al. 1993).

Antiquality factors have been reported to limit forage utilization in some tropical pastures (Hammond 1987). Tannins form complexes with plant proteins, and these complexes decrease the rate of digestion (degradability) and increase the amount of plant protein bypassing the rumen (Norton 1994). The antiquality effects of tannins in cattle are not clear, but tannins do cause an astringent taste that limits voluntary intake and diminishes protein and dry-matter digestibility in some mammals (Robbins et al. 1987). Ocumpaugh et al. (2001) indicate that Desmanthus species have some tannins, which tend to prevent its overuse, especially when the plant is in stress, and will be likely to prevent bloat.

Illinois bundleflower (Desmanthus illinoensis [Michx.] MacM.) is a useful plant for range and pasture seeding mixtures (Dovel et al. 1990) that is readily eaten by all types of livestock and wildlife (Muncrief and Heizer 1985). Adjei and Pitman (1993) reported a CP value of $21 \%-23 \%$ in leaves and $5 \%-8 \%$ in stems. Kunz (2002) reported moderate concentration of tannins in experimental accession BEDES-57 (Desmanthus bicornutus) and Illinois bundleflower.

Desmanthus virgatus (L.) Willd, has been recently reclassified as Desmanthus pubescens (L.) Willd. Because some publications use the old scientific name, in this publication the plant will be referred to as desmanthus. Desmanthus, a small shrub with high palatability and succulent regrowth (Muir and Pitman 1991), extends into the dry period when other species are dormant (Gardiner and Burt 1995). Desmanthus is readily consumed by cattle (Pitman et al. 1988), showing potential as a forage plant (Grichar et al. 1998) that could improve the diet quality of animals during dry seasons (Ortega et al. 1996). A mechanical blend of 4 bundleflower cultivars released by the Texas Agricultural Experiment Station is now being marketed as 'Beewild,' and is a palatable source of nutrition for domestic livestock and white-tailed deer (Odocoileus virginianus Texanus) (Ocumpaugh et al. 2004).

Both legumes are native, perennial, warm-season shrubs. Illinois bundleflower is distributed from central Texas to the northern United States and desmanthus ranges from Guatemala, Belize, and Mexico to southern Texas (Luckow 1993).

Kleingrass is widely grown in Texas and was identified among the warm-season African grasses recognized for their persistence and forage production (Cox et al. 1988). Kleingrass is widely used in the southern United States because of its drought tolerance, efficient water use, and palatability (Clark and Lugg 1986).

The objective of this study was to evaluate the nutrient content of kleingrass-Illinois bundleflower and kleingrassdesmanthus mixtures and generate information about the nutritive value of the mixtures for potential use by herbivores.

\section{MATERIALS AND METHODS}

A 2-year study (1993 and 1994) was conducted at the Texas A\&M University farm, $11 \mathrm{~km}$ west of College Station, Texas (lat $30^{\circ} 38^{\prime} \mathrm{N}$, long $90^{\circ} 20^{\prime} \mathrm{W}$ ). Desmanthus and Illinois bundleflower 'Sabine' were seeded at 3 different row-spacings in association with kleingrass 'Selection 75'. The study was seeded on prepared Weswood silty clay loam soil. This soil has a $\mathrm{pH}$ of 7.8 and organic matter content of $1.84 \%$. The site is well drained, with moderate runoff and permeability. The soil is low in nitrogen and has high levels of phosphorus (P). Mean annual temperature is $20^{\circ} \mathrm{C}$ and annual rainfall is $992 \mathrm{~mm}$ with peaks from April through May and in September (Fig. 1).

Plots $(5.48 \times 1.83 \mathrm{~m})$ were drilled at $0.15 \mathrm{~m}$ row-spacings, with the kleingrass being sown either alone or in association with a legume. Row-spacings between legume rows were 0.30, 0.60 , or $0.90 \mathrm{~m}$. Plots were planted in April and harvested at 60,90 , and 120 days after planting. The density of legume or kleingrass seed planted per $\mathrm{m}$ of row was the same in each treatment, but because of the different row-spacings, the seeding rates or number of plants $\mathrm{ha}^{-1}$ varied. One hundred pure live seed (PLS) $\mathrm{m}^{-1}$ of kleingrass (equivalent to $3.0 \mathrm{~kg}$ PLS $\mathrm{ha}^{-1}$ in case of control treatment $)$ or legume $\left(3.5 \mathrm{~kg} \cdot \mathrm{ha}^{-1}\right.$ in $0.90 \mathrm{~m}$ row-spacing) were planted. Both legumes were scarified by immersing the seeds for 5 minutes in hot water at $80^{\circ} \mathrm{C}$ (Burrows and Porter 1993). Fertilization and irrigation were not applied. The legumes were planted by hand at a $20 \mathrm{~mm}$ depth and the kleingrass was seeded to a depth of $5 \mathrm{~mm}$ using a hand planter. The study was repeated in 1994.

Two samples per plot were clipped to a height of $50 \mathrm{~mm}$ using a frame measuring $0.18 \mathrm{~m}^{2}$ at 60,90 , and 120 days. Samples were dried to a constant weight in a forced-air oven at $55^{\circ} \mathrm{C}$ and ground with a Wiley mill to pass through a $2.0 \mathrm{~mm}$ screen. Each sample was reground through a cyclone-type mill to pass through a $0.5 \mathrm{~mm}$ screen. In the second year (1994) legume species were separated into leaf and stem components.

Forage samples were evaluated for $\mathrm{CP}$, neutral detergent fiber (NDF), acid detergent fiber (ADF), tannins, and the following minerals: $\mathrm{P}$, calcium $(\mathrm{Ca})$, potassium $(\mathrm{K})$, sodium $(\mathrm{Na})$, magnesium $(\mathrm{Mg})$, iron $(\mathrm{Fe})$, copper $(\mathrm{Cu})$, zinc $(\mathrm{Zn})$, and manganese $(\mathrm{Mn})$. Crude protein was analyzed using the Kjeldahl Method (AOAC 1994). ADF and NDF were determined 
according to the procedures described by Georing and Van Soest (1970). Tannins were analyzed using the Vanillin- $\mathrm{HCl}$ procedure (Burns 1971). Since leaves and stems were separated and analyzed independently during the second year of field study, the chemical composition of the whole plant was estimated by multiplying its composition (CP, NDF, etc.) by the percent of leaf or stem components at each harvest date. Yield of $\mathrm{CP} \mathrm{ha}{ }^{-1}$ was estimated on a whole-plant basis and for leaves.

Data were evaluated using analysis of variance for a 3 -factor factorial experiment arranged in a randomized complete block design with 3 replications (Snedecor and Cochran 1980). Treatment means were separated by least significant difference, and standard errors were calculated for all means.

\section{RESULTS AND DISCUSSION}

No year-related effects or interactions of year with main factors were found for either kleingrass or legume quality traits $(P>0.05)$ despite the differences in distribution and total rainfall between years. As described by Buxton and Casler (1993), most environmental stresses have a greater effect on plant yield than on digestibility or quality-related traits. Rowspacing did not affect the variables of either grass or legumes and data on row-spacing are not presented.

\section{Kleingrass (Alone or in Mixtures)}

Plant age was the only significant source of variation affecting kleingrass quality $(\mathrm{P}<0.05)$. Kleingrass $\mathrm{CP}$ declined from $15.3 \% \pm 0.9 \%$ at 60 days to $6.2 \% \pm 0.3 \%$ at 120 days (Fig. 2). NDF and ADF increased with plant age. Kleingrass NDF increased from $66.7 \% \pm 1.1 \%$ at 60 days to $72.1 \% \pm 0.9 \%$ at 120 days, while $\mathrm{ADF}$ increased from $33.2 \% \pm 0.7 \%$ at 60 days to $38.7 \% \pm 1.0 \%$ at 120 days. As described by Nelson and Moser (1994), maturity is the main factor affecting morphology and determining forage quality, because the leaf to stem ratio decreases and the quality of stems declines as plants age. It is also important to consider that all this work was done during the establishment year, when perennial plants often exhibit higher nutritive value.

\section{Legumes (Whole Plant)}

Mean CP content was greater $(P<0.05)$ for Illinois bundleflower $(16.7 \% \pm 2.1 \%)$ than for desmanthus $(14.6 \% \pm 3.2 \%)$. $\mathrm{CP}$ decreased with age in both legumes; desmanthus showed a greater reduction in whole plant $\mathrm{CP}$ than did Illinois bundleflower. Both legumes had $20.6 \% \pm 0.8 \% \mathrm{CP}$ at 60 days, but desmanthus declined to $10.2 \% \pm 0.5 \%$ at 120 days and Illinois bundleflower declined to $13.6 \% \pm 0.3 \%$ (Fig. 2). Differences in $\mathrm{CP}$ concentration between the legumes were attributed to Illinois bundleflower having more leaves than did desmanthus (50\% vs. $30 \%$ of the dry mass [DM]) at 120 days. Skerman et al. (1988) reported similar CP values in desmanthus at 91 and 122 days of age $(12.2 \%$ and $10.5 \%$, respectively), and lower $\mathrm{CP}$ at 61 days $(10.5 \%)$ than the values observed in this study. However, Ocumpaugh et al. (2004) reported more than $20 \% \mathrm{CP}$ in several accessions of desmanthus, which was close to the $20.6 \%$ of this evaluation. There was also difference in the $\mathrm{CP}$ of the 2 legume species, with Illinois bundleflower's mean CP being higher than that of desmanthus. A significant legume $\cdot$ age interaction was

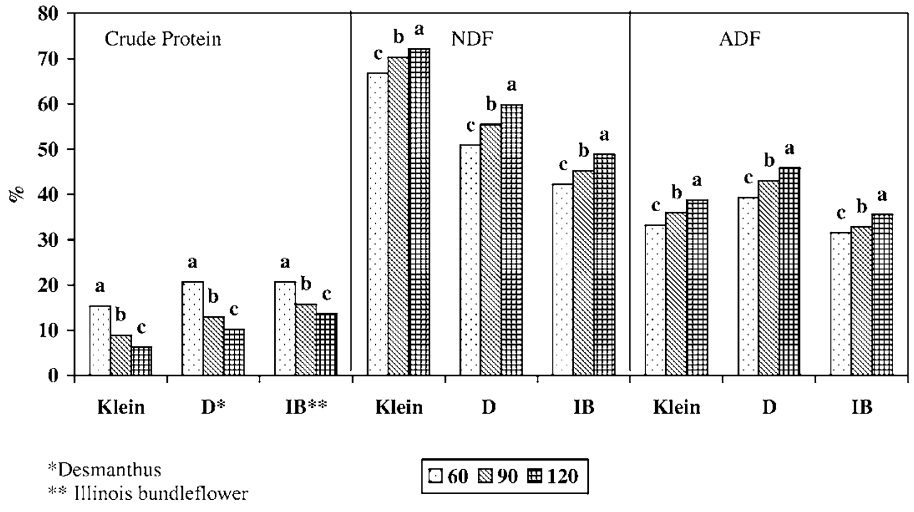

Figure 2. Effect of age on percent $C P, N D F$, and ADF of kleingrass associated with desmanthus and Illinois bundleflower (whole plant) during the establishment year. Bars with the same letter within group are not significantly different at $P<0.05$.

observed, which was attributed to desmanthus declining more rapidly in $\mathrm{CP}$ with age than did Illinois bundleflower.

Differences in NDF content were observed between desmanthus and Illinois bundleflower $(P<0.05)$. Desmanthus had a greater mean $\mathrm{NDF}(55.3 \% \pm 2.6 \%)$ than did Illinois bundleflower $(45.4 \% \pm 1.9 \%)$ as a result of having a greater abundance of stems. NDF increased with age and the observed interaction of age $\cdot$ legume was due to desmanthus' increase in NDF from 60 to 120 days being greater than Illinois bundleflower's NDF increase during the same period.

ADF followed a similar trend as NDF with desmanthus having a greater mean $(P<0.05) \mathrm{ADF}(42.7 \% \pm 1.9 \%)$ than did Illinois bundleflower $(33.3 \% \pm 1.2 \%)$. There was a significant legume $\cdot$ age interaction for ADF, which was attributed to a faster rate of increase in ADF for desmanthus than for Illinois bundleflower. Desmanthus increased 9\% in ADF from 60 to 90 days compared to a $4 \%$ increase for Illinois bundleflower. On the other hand, Illinois bundleflower showed a greater increase than desmanthus from 90 to 120 days ( $8 \%$ Illinois bundleflower vs. $6 \%$ desmanthus). The greater increase in ADF content of Illinois bundleflower from 90 to 120 days was attributed to leaf drop and seed production during this period.

\section{Legumes (Leaves and Stems)}

Because leaves are the main diet component of animals eating bundleflower, leaves and stems were analyzed separately. Mean $\mathrm{CP}$ of desmanthus leaves was greater $(P<0.05)$ than the mean $\mathrm{CP}$ of Illinois bundleflower (Table 1). Although no difference $(P>0.05)$ in the mean CP of stems was detected between species, Illinois bundleflower had a greater whole-plant $\mathrm{CP}$ than did desmanthus (Fig. 2). The mean CP of desmanthus is consistent with that reported by Gutteridge (1994), who measured $24 \%-30 \%$ CP in desmanthus leaves. The CP values for Illinois bundleflower are consistent with those $(23 \%)$ reported by Adjei and Pitman (1993).

The CP concentration in the leaves declined with age. A significant $(P<0.05)$ legume $\cdot$ age interaction for leaf $\mathrm{CP}$ was observed and attributed to the CP concentration of desmanthus being more affected by age (with a $21 \%$ reduction in $\mathrm{CP}$ from 60 to 120 days vs. a $17 \%$ reduction in Illinois bundleflower) 
Table 1. Effect of age on CP, NDF, and ADF concentration (\%) of Illinois bundleflower and desmanthus (leaves and stems)(x \pm SE). ${ }^{1}$

\begin{tabular}{|c|c|c|c|c|c|c|c|}
\hline \multirow[b]{2}{*}{ Species } & \multirow{2}{*}{$\begin{array}{l}\text { Days after } \\
\text { planting }\end{array}$} & \multicolumn{3}{|c|}{ Leaves } & \multicolumn{3}{|c|}{ Stems } \\
\hline & & $\mathrm{CP}$ & NDF & ADF & $\mathrm{CP}$ & NDF & ADF \\
\hline \multirow[t]{3}{*}{$D^{2}$} & 60 & $32.6 \pm 1.0 \mathrm{a}$ & $14.0 \pm 0.9 f$ & $9.3 \pm 0.6 f$ & $14.1 \pm 1.1 \mathrm{a}$ & $70.7 \pm 1.80 \mathrm{c}$ & $54.7 \pm 1.12 \mathrm{~cd}$ \\
\hline & 90 & $29.3 \pm 0.7 b$ & $16.0 \pm 0.9 \mathrm{e}$ & $10.8 \pm 0.8 d$ & $6.5 \pm 0.8 \mathrm{c}$ & $72.8 \pm 1.54 b$ & $57.0 \pm 1.67 b$ \\
\hline & 120 & $25.8 \pm 0.6 d$ & $21.1 \pm 0.9 b$ & $13.9 \pm 0.7 b$ & $4.3 \pm 0.7 d$ & $76.7 \pm 1.24 \mathrm{a}$ & $58.9 \pm 1.23 a$ \\
\hline Mean & & $29.2 \pm 1.0 b$ & $17.1 \pm 0.9 d$ & $11.3 \pm 0.9 \mathrm{~cd}$ & $8.3 \pm 0.9 b$ & $73.4 \pm 1.56 b$ & $56.9 \pm 1.33 b$ \\
\hline \multirow[t]{3}{*}{$\mathrm{IB}^{3}$} & 60 & $27.4 \pm 0.8 c$ & $15.1 \pm 1.0 \mathrm{e}$ & $10.2 \pm 0.7 \mathrm{e}$ & $13.9 \pm 0.9 a$ & $69.9 \pm 1.86 c$ & $52.7 \pm 1.00 \mathrm{e}$ \\
\hline & 90 & $24.7 \pm 0.8 \mathrm{e}$ & $18.0 \pm 1.0 \mathrm{~cd}$ & $11.1 \pm 0.7 \mathrm{~d}$ & $7.1 \pm 0.7 c$ & $72.6 \pm 1.35 b$ & $54.6 \pm 1.54 c$ \\
\hline & 120 & $22.7 \pm 0.7 f$ & $24.0 \pm 1.1 \mathrm{a}$ & $15.1 \pm 0.8 \mathrm{a}$ & $5.0 \pm 0.7 d$ & $73.4 \pm 1.46 b$ & $56.0 \pm 1.46 b c$ \\
\hline Mean & & $24.9 \pm 0.8 \mathrm{e}$ & $19.0 \pm 1.0 \mathrm{c}$ & $12.1 \pm 1.0 \mathrm{c}$ & $8.7 \pm 0.8 b$ & $72.0 \pm 1.67 \mathrm{bc}$ & $54.4 \pm 1.35 d$ \\
\hline
\end{tabular}

${ }^{1}$ Means in columns followed by the same letter are not significantly different $(P>0.05)$.

${ }^{2}$ Desmanthus.

${ }^{3}$ Illinois bundleflower.

than was Illinois bundleflower. Stem CP was affected also by age and decreased from $14.0 \%$ (mean of both legumes) at 60 days to $4.6 \%$ at 120 days (Table 1 ).

Mean leaf NDF was greater $(P<0.05)$ in Illinois bundleflower $(19.0 \% \pm 1.0 \%)$ than in desmanthus $(17.1 \% \pm 0.9 \%)$ (Table 1). NDF increased with leaf age and a significant legume $\cdot$ age interaction was also detected. The interaction was attributed to Illinois bundleflower increasing in NDF faster than did desmanthus. The significant effect of legume species on stem NDF was perhaps due to desmanthus having more fibrous or lignified stems than those of Illinois bundleflower.

Mean leaf ADF followed similar trends as NDF, with Illinois bundleflower $(12.1 \% \pm 1.0 \%)$ having a greater $(P<0.05)$ ADF than did desmanthus $(11.3 \% \pm 0.9 \%)$. ADF increased with plant age, with desmanthus having a greater concentration of ADF than that of Illinois bundleflower.

\section{Crude Protein Yield}

The CP yield of the mixtures (considering the legume whole plant plus kleingrass) was affected by age, with the greatest production $(P<0.05)$ observed 120 days after planting with $960 \pm 47 \mathrm{~kg} \cdot \mathrm{ha}^{-1}$ in the desmanthus-kleingrass association (Table 2). The type of association also affected the CP yield,

Table 2. Mean crude protein yield $\left(\mathrm{kg} \cdot \mathrm{ha}^{-1}\right)$ of kleingrass associated with desmanthus and Illinois bundleflower considering the whole legumes.

\begin{tabular}{lccc}
\hline & \multicolumn{3}{c}{ Age (days) } \\
\cline { 2 - 4 } Association & 60 & 90 & 120 \\
\hline Grass only & $194 \pm 29$ & $220 \pm 38$ & $206 \pm 32$ \\
D-K & $618 \pm 84$ & $625 \pm 89$ & $960 \pm 104$ \\
IB-K & $527 \pm 71$ & $495 \pm 81$ & $466 \pm 55$ \\
Contrasts: & $*$ & $*$ & \\
$\quad$ Grass vs. both legumes & $\star$ & $*$ & $*$ \\
Grass vs. D-K & $*$ & $*$ & $*$ \\
Grass vs. IB-K & $*$ & $*$ & $*$ \\
D-K vs. IB-K & & & $*$ \\
\hline
\end{tabular}

\footnotetext{
${ }^{1}$ Desmanthus-kleingrass.

${ }^{2}$ Illinois bundleflower-kleingrass.

${ }^{*}$ Significant $(P<0.05)$.
}

with the lowest production being observed for the kleingrass monoculture. The increase in CP yield of the mixtures was attributed only to an increase in leaf yield of desmanthus with age and was not due to an increase in CP concentration. An age $\cdot$ association interaction was observed, which was attributed to the grass monoculture and Illinois bundleflowerkleingrass mixtures decreasing in CP yield from 90 to 120 days while the desmanthus-kleingrass association increased.

CP yield of mixtures consisting only of leaves of legumes plus the kleingrass showed similar trends to those observed in the whole-legume basis. Kleingrass monoculture gave the lowest yield (206 $\pm 18 \mathrm{~kg} \cdot \mathrm{ha}^{-1}$ at 120 days) followed by Illinois bundleflower-kleingrass $\left(404 \pm 41 \mathrm{~kg} \cdot \mathrm{ha}^{-1}\right.$ at 120 days), with desmanthus-kleingrass providing the greatest $\mathrm{CP}$ yield (748 $\pm 47 \mathrm{~kg} \cdot \mathrm{ha}^{-1}$ at 120 days) (Table 3$)$. Although the DM yield of mixtures (when considering the legume leaves only) was lower in some cases than the monoculture, the mixtures always had greater CP yield due to the higher $\mathrm{CP}$ content. The significant age $\cdot$ association interaction was attributed to the continued increase in yield of the desmanthus-kleingrass association with age, while the Illinois bundleflower-kleingrass mixture and kleingrass alone showed no change from 90 to 120 days.

Table 3. Crude protein yield $\left(\mathrm{kg} \cdot \mathrm{ha}^{-1}\right)$ of kleingrass associated with desmanthus and Illinois bundleflower mixtures considering only the leaves of the legumes.

\begin{tabular}{lccc}
\hline & \multicolumn{3}{c}{ Age (days) } \\
\cline { 2 - 4 } Association & 60 & 90 & 120 \\
\hline Grass only & $194 \pm 23$ & $220 \pm 28$ & $206 \pm 18$ \\
D-K & $405 \pm 38$ & $449 \pm 33$ & $748 \pm 47$ \\
IB-K & $238 \pm 21$ & $415 \pm 27$ & $404 \pm 41$ \\
Contrasts: & & & $*$ \\
$\quad$ Grass vs. both legumes & $*$ & $*$ & $*$ \\
$\quad$ Grass vs. D-K & $*$ & $*$ & $*$ \\
$\quad$ Grass vs. IB-K & $*$ & $*$ & $*$ \\
$\quad$ D-K vs. IB-K & $*$ & $*$ & \\
\hline${ }^{1}$ Desmanthus-kleingrass. & & & \\
${ }^{2}$ Illinois bundleflower-kleingrass. & &
\end{tabular}




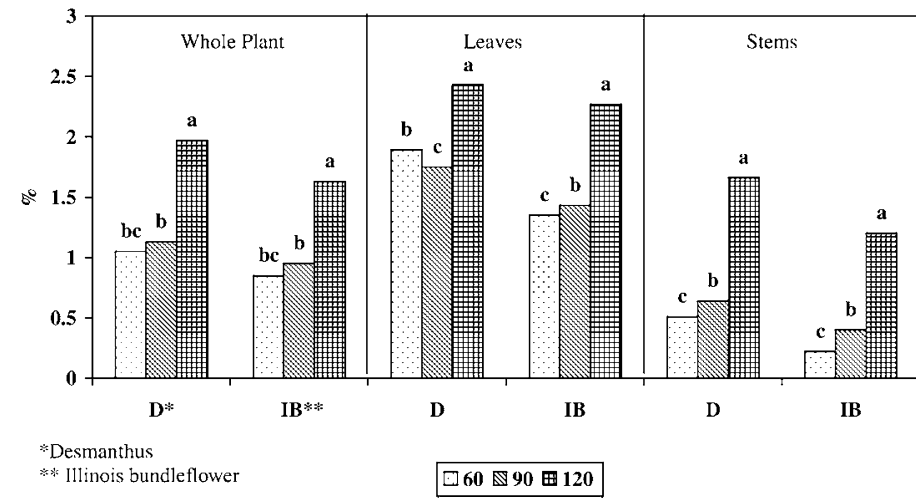

Figure 3. Tannin concentration of kleingrass associated with Illinois bundleflower and desmanthus during the establishment year. Bars with the same letter within group are not significantly different at $P<0.05$.

\section{Tannins}

There was no effect of year $(P>0.05)$ on whole-plant tannin concentration. Desmanthus had the highest tannin content $(P<0.05)$, with a mean of $1.38 \% \pm 0.8 \%$ vs. $1.14 \% \pm 0.07 \%$ for Illinois bundleflower (Fig. 3). The tannin content of both legumes increased with age, mainly from 90 to 120 days. The leaves of desmanthus had a greater tannin concentration than did Illinois bundleflower leaves, with a mean of $2.11 \% \pm 0.11 \%$ vs. $1.68 \% \pm 0.008 \%$, respectively (Fig. 3). The greatest tannin concentration $(P<0.05)$ was found at 120 days in both legumes where concentrations of $2.68 \% \pm 0.12 \%$ and $2.27 \% \pm 0.09 \%$ were observed in desmanthus and Illinois bundleflower, respectively. Stems of both species had a lower tannin concentration but followed a trend similar to that found in the leaves.
Tannin in the diet can impact animal nutrition. The presence of tannins is usually considered detrimental to ruminants, but low levels of tannins can have some beneficial properties (Kunz 2002). Douglas et al. (1993) reported that forages containing $2.0 \%-4.0 \%$ condensed tannins enhance nutritive value for grazing ruminants by increasing protein absorption from the intestine without depressing rumen fiber digestion or voluntary intake.

\section{Minerals}

No significant year-related effects and no interactions of year with species (legume or grass) or age were detected $(P>0.05)$ for mineral content. With the exception of $\mathrm{Ca}$, all minerals decreased with age in both Illinois bundleflower and desmanthus on a whole-plant basis (Table 4). In general, mineral concentrations of leaf tissue (Table 5) followed the whole-plant trends. One exception to this trend in whole-plant mineral concentration was the lack of change in $\mathrm{Fe}$ in the leaves with increasing age (Table 5). Spears (1994) indicated that with advanced maturity there is a dilution in mineral content attributed to a large increase in DM; however, $\mathrm{Ca}$ is reported to be unaffected by maturity (Ammerman et al. 1982).

In this study, the concentrations of $\mathrm{K}, \mathrm{Na}, \mathrm{Cu}$, and $\mathrm{Mn}$ were higher $(P<0.05)$ in kleingrass, and $\mathrm{Ca}$ and $\mathrm{Mg}$ levels were higher in legumes. Phosphorus and $\mathrm{Zn}$ concentrations were similar $(P>0.05)$ in kleingrass and legumes (leaves or whole-plant basis). Iron (legume whole-plant) was greater $(P<0.05)$ in Illinois bundleflower $\left(170 \pm 7.4 \mathrm{mg} \cdot \mathrm{kg}^{-1}\right)$ than in desmanthus or kleingrass $\left(134 \pm 16.5\right.$ and $146 \pm 10.2 \mathrm{mg} \cdot \mathrm{kg}^{-1}$, respectively) (Table 4), but the concentration of $\mathrm{Fe}$ in legume leaves was similar $(P>0.05)$ in both legumes and greater $(P<0.05)$ than in kleingrass (Table 5$)$. Considering the mineral requirements reported by McDowell et al. (1993), the P, Zn, and

Table 4. Mineral concentration in legumes (whole plant) and kleingrass planted in association.

\begin{tabular}{|c|c|c|c|c|c|c|c|c|c|c|}
\hline Species & $\begin{array}{c}\text { Age } \\
\text { (days) }\end{array}$ & $P$ & K & $\mathrm{Ca}$ & $\mathrm{Mg}$ & $\mathrm{Na}$ & $\mathrm{Zn}$ & $\mathrm{Fe}$ & $\mathrm{Cu}$ & $\mathrm{Mn}$ \\
\hline & & 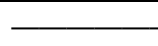 & $g \cdot h$ & & - & 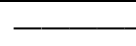 & 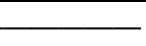 & $\mathrm{mg} \cdot \mathrm{kg}^{-1}$ & & \\
\hline \multirow[t]{3}{*}{$D^{1}$} & 60 & $2.57 \pm 0.20$ & $15.23 \pm 1.03$ & $6.57 \pm 0.67$ & $3.07 \pm 0.23$ & $286 \pm 19$ & $27 \pm 1.8$ & $166 \pm 12$ & $5 \pm 0.14$ & $18 \pm 1.10$ \\
\hline & 90 & $1.24 \pm 0.14$ & $10.94 \pm 1.10$ & $7.64 \pm 0.58$ & $2.11 \pm 0.21$ & $241 \pm 13$ & $16 \pm 1.17$ & $122 \pm 14$ & $4 \pm 0.32$ & $22 \pm 0.99$ \\
\hline & 120 & $1.35 \pm 0.12$ & $7.58 \pm 0.92$ & $8.66 \pm 1.06$ & $2.42 \pm 0.18$ & $213 \pm 21$ & $18 \pm 1.12$ & $114 \pm 13$ & $4 \pm 0.24$ & $17 \pm 0.84$ \\
\hline \multirow[t]{3}{*}{$\mathrm{IB}^{2}$} & 60 & $2.24 \pm 0.19$ & $14.3 \pm 0.98$ & $10.42 \pm 1.12$ & $3.62 \pm 0.24$ & $321 \pm 22$ & $22 \pm 0.99$ & $184 \pm 23$ & $6 \pm 0.43$ & $35 \pm 1.97$ \\
\hline & 90 & $1.51 \pm 0.13$ & $11.66 \pm 1.01$ & $9.50 \pm 1.13$ & $3.11 \pm 0.13$ & $164 \pm 15$ & $22 \pm 1.00$ & $159 \pm 13$ & $5 \pm 0.15$ & $38 \pm 1.24$ \\
\hline & 120 & $1.26 \pm 0.14$ & $8.2 \pm 0.94$ & $9.75 \pm 0.87$ & $3.22 \pm 0.19$ & $141 \pm 17$ & $21 \pm 1.12$ & $168 \pm 11$ & $5 \pm 0.28$ & $32 \pm 1.09$ \\
\hline \multirow[t]{3}{*}{ Kleingrass } & 60 & $2.25 \pm 0.30$ & $22.91 \pm 1.93$ & $3.59 \pm 0.07$ & $1.97 \pm 0.14$ & $303 \pm 19$ & $25 \pm 1.22$ & $165 \pm 21$ & $11 \pm 0.57$ & $54 \pm 2.10$ \\
\hline & 90 & $1.66 \pm 0.21$ & $16.72 \pm 1.35$ & $3.43 \pm 0.32$ & $1.93 \pm 0.21$ & $299 \pm 18$ & $22 \pm 1.03$ & $142 \pm 10$ & $9 \pm 0.41$ & $47 \pm 1.91$ \\
\hline & 120 & $1.10 \pm 0.10$ & $15.27 \pm 1.40$ & $3.52 \pm 0.12$ & $1.99 \pm 0.18$ & $294 \pm 15$ & $20 \pm 0.91$ & $131 \pm 15$ & $7 \pm 0.38$ & $51 \pm 2.13$ \\
\hline \multicolumn{11}{|l|}{ Contrasts: } \\
\hline Grass vs. legumes & & $N S^{3}$ & * & * & * & * & NS & NS & * & * \\
\hline Grass vs. D & & NS & * & * & * & * & NS & NS & * & * \\
\hline Grass vs. IB & & NS & * & * & * & * & NS & * & * & * \\
\hline D vs. IB & & NS & NS & * & * & * & NS & * & NS & * \\
\hline
\end{tabular}

${ }^{1}$ Desmanthus.

${ }^{2}$ Illinois bundleflower.

${ }^{3} \mathrm{NS}=$ nonsignificant $(P>0.05)$.

${ }^{\star}$ Significant $(P<0.05)$. 
Table 5. Mineral concentration in legume leaves and kleingrass planted in association.

\begin{tabular}{|c|c|c|c|c|c|c|c|c|c|c|}
\hline Species & $\begin{array}{c}\text { Age } \\
\text { (days) }\end{array}$ & $P$ & K & $\mathrm{Ca}$ & $\mathrm{Mg}$ & $\mathrm{Na}$ & $\mathrm{Zn}$ & $\mathrm{Fe}$ & $\mathrm{Cu}$ & $\mathrm{Mn}$ \\
\hline & & & - & & & & & $\mathrm{mg} \cdot \mathrm{kg}^{-1}$ & & \\
\hline \multirow[t]{3}{*}{$D^{1}$} & 60 & $3.20 \pm 0.21$ & $18.40 \pm 0.21$ & $9.75 \pm 0.07$ & $5.82 \pm 0.39$ & $254 \pm 21$ & $30 \pm 2.11$ & $219 \pm 18$ & $6 \pm 0.43$ & $39 \pm 1.90$ \\
\hline & 90 & $1.92 \pm 0.18$ & $13.54 \pm 0.08$ & $14.65 \pm 0.11$ & $4.63 \pm 0.46$ & $240 \pm 18$ & $20 \pm 3.02$ & $200 \pm 19$ & $7 \pm 0.39$ & $39 \pm 2.57$ \\
\hline & 120 & $1.73 \pm 0.10$ & $9.29 \pm 0.11$ & $13.59 \pm 0.15$ & $4.42 \pm 0.38$ & $218 \pm 24$ & $19 \pm 2.43$ & $195 \pm 15$ & $5 \pm 0.52$ & $33 \pm 2.38$ \\
\hline \multirow[t]{3}{*}{$\mathrm{IB}^{2}$} & 60 & $2.69 \pm 0.23$ & $15.10 \pm 0.15$ & $14.12 \pm 0.13$ & $5.55 \pm 0.51$ & $352 \pm 17$ & $22 \pm 3.10$ & $272 \pm 21$ & $5 \pm 0.31$ & $55 \pm 5.02$ \\
\hline & 90 & $2.11 \pm 0.16$ & $13.66 \pm 0.12$ & $12.8 \pm 0.09$ & $4.82 \pm 0.34$ & $181 \pm 29$ & $23 \pm 2.75$ & $231 \pm 22$ & $6 \pm 0.47$ & $61 \pm 5.27$ \\
\hline & 120 & $1.38 \pm 0.11$ & $7.91 \pm 0.06$ & $12.90 \pm 0.11$ & $4.87 \pm 0.32$ & $156 \pm 13$ & $18 \pm 2.04$ & $258 \pm 24$ & $5 \pm 0.48$ & $46 \pm 3.09$ \\
\hline \multirow[t]{3}{*}{ Kleingrass } & 60 & $2.26 \pm 0.19$ & $22.91 \pm 0.23$ & $3.59 \pm 0.05$ & $1.97 \pm 0.12$ & $303 \pm 25$ & $25 \pm 0.29$ & $165 \pm 13$ & $11 \pm 0.14$ & $54 \pm 3.85$ \\
\hline & 90 & $1.67 \pm 0.16$ & $16.72 \pm 0.14$ & $3.43 \pm 0.21$ & $1.93 \pm 0.10$ & $299 \pm 16$ & $22 \pm 1.81$ & $142 \pm 13$ & $9 \pm 0.10$ & $47 \pm 2.96$ \\
\hline & 120 & $1.10 \pm 0.09$ & $15.27 \pm 0.20$ & $3.52 \pm 0.27$ & $1.99 \pm 0.33$ & $294 \pm 18$ & $20 \pm 1.76$ & $131 \pm 16$ & $7 \pm 0.46$ & $51 \pm 4.12$ \\
\hline \multicolumn{11}{|l|}{ Contrasts: } \\
\hline Grass vs. legumes & & * & * & * & * & * & NS & * & * & NS \\
\hline Grass vs. D & & * & * & * & * & * & NS & * & * & NS \\
\hline Grass vs. IB & & $\star$ & * & * & * & * & NS & NS & * & * \\
\hline D vs. IB & & $\mathrm{NS}^{3}$ & NS & NS & NS & NS & NS & NS & * & * \\
\hline
\end{tabular}

${ }^{1}$ Desmanthus.

${ }^{2}$ Illinois bundleflower.

${ }^{3} \mathrm{NS}=$ nonsignificant $(P>0.05)$

${ }^{\star}$ Significant $(P<0.05)$.

$\mathrm{Cu}$ concentrations of all the forages in this study were deficient for animal production.

Leaves of desmanthus and Illinois bundleflower had a greater $(P<0.05)$ level of $\mathrm{P}\left(2.28\right.$ and $2.06 \mathrm{~g} \cdot \mathrm{kg}^{-1}$, respectively $)$ than kleingrass $\left(1.67 \mathrm{~g} \cdot \mathrm{kg}^{-1}\right)$ (Table 5). There was a significant legume $\cdot$ age interaction for $\mathrm{P}$ concentration in leaves. This was attributed to desmanthus having the same level at 90 and 120 days, but Illinois bundleflower decreasing in $\mathrm{P}$ as age increased from 90 to 120 days. The content of $\mathrm{Na}, \mathrm{Zn}, \mathrm{Fe}$, and $\mathrm{Cu}$ in leaves was similar in both legume species, but $\mathrm{Mg}$ was higher in Illinois bundleflower $\left(54 \mathrm{mg} \cdot \mathrm{kg}^{-1}\right)$ than in desmanthus $(35$ $\left.\mathrm{mg} \cdot \mathrm{kg}^{-1}\right)$. A legume $\cdot$ age interaction $(P<0.05)$ was observed in leaves for Na content. Desmanthus had the same Na level at 60 and 90 days and a lower value at 120 days; Illinois bundleflower had the same $\mathrm{Na}$ level at 90 and 120 days. Legume $\cdot$ age interaction for $\mathrm{Zn}$ in leaves was observed, which was attributed to a reduction in $\mathrm{Zn}$ concentration from 60 to 90 days in desmanthus, while no change in $\mathrm{Zn}$ was observed in Illinois bundleflower.

\section{CONCLUSIONS}

The CP, NDF, and ADF of kleingrass were not affected by the associated legume species or by spacing between the legumes' rows. Age was the only factor that negatively influenced the nutritional value of kleingrass.

The CP concentration of desmanthus leaves was greater than that of Illinois bundleflower; however, because Illinois bundleflower is more leafy ( $50 \%$ of the total biomass) than desmanthus ( $30 \%$ leaves) the $\mathrm{CP}$ on a whole-plant basis was greater in Illinois bundleflower.

The NDF and ADF of legume leaves were greater in Illinois bundleflower, but desmanthus had a greater fiber concentration on a whole-plant basis, because desmanthus had a greater proportion of stems $(70 \% \mathrm{DM})$ than did Illinois bundleflower $(50 \%)$, and the NDF and ADF concentrations of desmanthus increased more with age.

The tannin content was greater in desmanthus than in Illinois bundleflower on a whole-plant, leaf, or stem basis. Leaves had the greatest tannin concentration with a mean of $2.11 \%$ and $1.68 \%$ in desmanthus and Illinois bundleflower, respectively. Further evaluations of the effect of tannin concentration on digestibility, CP digestion, and animal voluntary intake are needed.

With the exception of $\mathrm{Ca}$, all minerals declined with age in kleingrass and in both legumes. Kleingrass had greater levels of $\mathrm{K}, \mathrm{Na}, \mathrm{Cu}$, and $\mathrm{Mn}$, and the legumes had greater concentrations of $\mathrm{Ca}$ and $\mathrm{Mg}$. Phosphorus and $\mathrm{Zn}$ were similar for kleingrass and legumes. With respect to $\mathrm{Fe}$, on a whole-plant basis Illinois bundleflower had a higher level than did either desmanthus or kleingrass, and Fe concentration of the legume leaves was greater in desmanthus than in kleingrass.

\section{MANAGEMENT IMPLICATIONS}

Associations with desmanthus or Illinois bundleflower did not affect the nutrient content of kleingrass. A positive effect is expected on the performance of ruminants grazing these associations because of the higher CP content of both legumes (greater than $20 \%$ in leaves of both Illinois bundleflower and desmanthus).

Calcium and magnesium concentration is higher in both legumes than in kleingrass, which may help to improve the minerals' availability in animal diets and reduce mineral supplementation expenses. 
Tannin content is greater in desmanthus than in Illinois bundleflower. However, the level found in both legumes is not considered to negatively affect animal performance. These levels may have some beneficial properties, enhancing nutritive value to grazing ruminants by increasing protein absorption at the intestinal level without depressing rumen fiber digestion or voluntary intake (Kunz 2001).

\section{LITERATURE CITED}

Adjel, M. B., And W. D. Pitman. 1993. Response of Desmanthus to clipping on a phosphatic clay mine-spoil. Tropical Grasslands 27:94-99.

Ammerman, C. B., J. E. Moore, P. R. Henry, S. M. Miller, and F. G. Martin. 1982. Effect of age and sample preparation on mineral concentration of bermudagrass hay. Journal of Dairy Sciences 65:1329-1333.

[AOAC] Association of Official Analytical Chemists. 1984. Official methods of analysis. 14th ed. Washington, DC: Journal of Association of Official Analyticial Chemists $1015 \mathrm{p}$.

BuRNs, R. E. 1971. Method for estimating tannins in grain sorghum. Agronomy Journal 63:511-512.

Burrows, D. M., And F. J. Porter. 1993. Regeneration and survival of Desmanthus pubescens 78382 in grazed and ungrazed pastures. Tropical Grasslands 23: 100-107.

Buxton, D. R., and M. D. Casler. 1993. Environmental and genetic effects on cell wall composition and digestibility. In: H. G. Jung, D. R. Buxton, R. D. Hatfield and J. Ralph [eds.]. Cell wall structure and digestibility. Madison, WI: ASA CSSA, and SSSA. p 685-714.

Clark, R. P., And D. G. LugG. 1986. Kleingrass yield and quality under three irrigation regimes when harvested at anthesis. Agronomy Journal 78 : 235-239.

Cox, J. R., M. H. Martin-R, F. A. Ibarra-F., J. H. Fourie, N. F. G. Rethman, and D. G. WILcox. 1988. The influence of climate and soils on the distribution of four African grasses. Journal of Range Management 41:127-137.

Douglas, G. C., P. Donkers, A. G. Foote, and T. N. Barry. 1993. Determining of extractable and bound condensed tannins in forage species. Proceedings of the XVII International Grassland Congress; 18-21 February 1993, Rockhampton, Australia. Palmerston North, New Zealand: New Zealand Grassland Association. p 204-206.

Dovel, R. L., M. A. Hussey, and E. C. Holt. 1990. Establishment and survival of Illinois bundleflower interseeded into an established kleingrass pasture. Journal of Range Management 43:153-156.

Gardiner, C. P., And R. L. BuRT. 1995. Performance characteristics of Desmanthus pubescens in contrasting tropical environments. Tropical Grasslands 29: 183-187.

Georing, H. K., and P. G. Van Soest. 1970. Forage Fiber Analysis (Apparatus, Reagents, Procedures, and some Applications). Washington, DC: ARS-USDA. USDA-ARS Handbook 379. 20 p.

Grichar, W. J., W. R. Ocumpaugh, A. Abrameit, M. A. Hussey, M. K. Owens, R. N. Rahmes, R. L. Reed, J. L. Reilley, M. A. Sanderson, and D. C. Sestak. 1998. Adaptation of Desmanthus virgatus to South Texas. In: Proc. American Forage and Grassland Council. Georgetown, TX: American Forage and Grassland Council. 7:46-49.

Gutteridge, R. C. 1994. Other species of multipurpose forage tree legumes. In: R. C. Gutteridge and H. M. Shelton [eds.]. Forage tree legumes in tropical agriculture. Wallingford, United Kingdom: CAB International. p 97-108.
Hammond, A. G. 1987. Chemical, anatomical, and other antiquality factors limiting forage utilization. In: Moore, J. E., K. H. Quesenberry, and H. W. Michaud [eds.]. Forage-livestock research needs for the Caribbean Basin. Gainesville, FL: Caribean Basin Advisory Group, Institute of Food and Agricultural Sciences, Univ. of Florida. p 59-69.

Holechek, J. L., R. D. Pieper, and C. H. Herbel. 2001. Range Management, Principles and Practices. 4th ed. Englewood Cliffs, NJ: Prentice Hall, Inc. $587 \mathrm{p}$.

Kunz, D. J. 2002. Evaluation of alternative warm-season forages for free-ranging white-tailed deer in south Texas [master's thesis]. Kingsville, TX: Texas A\&M University-Kingsville. $132 \mathrm{p}$.

Luckow, M. 1993. Systematic Botany Monographs. Monograph of Desmanthus. Volume 38. Ann Arbor, MI: American Society of Plant Taxonomists. $166 \mathrm{p}$.

McDowell, L. R., J. H. Conrad, F. G. Hembry, L. X. Rojas, G. Valle, and J. Velasouez. 1993. Minerales para rumiantes en pastoreo en regiones tropicales. Gainsville, FL: University of Florida Gainesville, AID-CBAG. 76 p.

McGinnies, W. J., AND C. E. Townsend. 1983. Yield of three range grasses grown alone and in mixtures of legumes. Journal of Range Management 3:399-402.

MuiR, J. P., AND W. D. Pitman. 1991. Grazing tolerance of warm-season legumes in peninsular Florida. Agronomy Journal 83:297-302.

Muncrief, J. B., And R. B. Heizer. 1985. Registration of Sabine Illinois bundleflower. Crop Sciences 25:1124.

Nelson, C. J., and L. E. Moser. 1994. Plant factors affecting forage quality. In: G. C. Fahey, M. Collins, D. R. Mertens, and L. E. Moser [eds.]. Forage quality, evaluation and utilization. Madison, WI: ASA, CSSA, and SSSA. p 115-154.

Norton, B. W. 1994. The nutritive value of tree legumes. In: R. C. Gutteridge and H. M. Shelton [eds.]. Forage tree legumes in tropical agriculture. Wallingford, United Kingdom: CAB International. p 177-191.

Ocumpaugh, W. R., D. Kunz, T. Ginnett, F. Bryant, and J. Grichar. 2001. Bundleflower for wildlife and livestock utilization in South Texas. Proceedings of the American Forage and Grassland Council. 10:185

Ocumpaugh, W. R., D. Kunz, J. Rahmes, D. Martinez, J. Grichar, M. Hussey, J. Reilley, A. Abrameit, K. Owens, R. Reed, J. P. Muir, and D. Bade. 2004. 'Beewild' bundleflower, a new summer-growing perennial legume for central and south Texas and Mexico. Forage Research in Texas. CPR 5267. Available at: http:// forageresearch.tamu.edu. Accessed 26 March 2005.

Ortega S., J. A., E. A. Gonzalez V., J. M. Avila C., and R. Guaneros A. 1996. Manejo y utilizacion de Desmanthus para la alimentacion de bovinos. Publicacion especial No. 3. Memorias del XIV dia del Ganadero del C. El. Aldama. p. 15.

Pitman, W. D., C. G. Chambliss, and A. E. Kretschmer, JR. 1988. Persistence of tropical legumes on peninsular Florida flatwoods (Spodosols) at two stocking rates. Tropical Grasslands 22:27-33.

Robbins, C. T., T. A. Hanley, A. E. Hagerman, 0. Hueljord, D. L. Baker, C. C. Schwartz, And W. W. Mautz. 1987. Role of tannins in defending plants against ruminants: reduction in protein availability. Ecology 68:98-107.

Skerman, P. J., D. G. Cameron, and F. Riveros. 1988. Tropical forage legumes. [FAO] Food and Agriculture Organization of the United Nations. Plant production and protection series. Rome, Italy: FAO. 609 p.

Skerman, P. J., AND F. Riveros. 1990. Tropical grasses. [FAO] Food and Agriculture Organization of the United Nations. Plant production and protection series. Rome, Italy: FAO. 692 p.

Snedecor, G. W., and W. G. Cochran. 1980. Statistical methods. Ames, IA: Iowa State Univ. Press. 693 p.

Spears, J. W. 1994. Minerals in forages. In: G. C. Fahey, M. Collins, D. R. Mertens, and L. E. Moser [EDS.]. Forage quality, evaluation, and utilization. Madison, WI: ASA, CSSA, and SSSA. p 281-317. 